\title{
Bergman's Theatre Is The Serious Game
}

\section{David Drozd}

Egil Törnqvist. The Serious Game: Ingmar Bergman as Stage Director. Amsterdam University Press, 2015. 276 pp.

The monograph The Serious Game: Ingmar Bergman as Stage Director is the last published book by Egil Törnqvist (1932-2015), theater and film scholar, specializing on the playwright August Strindberg and the theatre- and filmmaker Ingmar Bergman. He dedicated many papers and several books to both of them (e.g., Strindberg's Miss Julie: A Play and its Transpositions, 1988; Between Stage and Screen: Ingmar Bergman Directs, 1995; Strindberg's The Ghost Sonata: From Text to Performance, 2000; Strindberg on Drama and Theatre, 2007). An actual book on Bergman, finished shortly before his death, could be seen as his final oeuvre. The book is based on his previous papers and essays; it consists of series of analytical chapters on particular performances, with two contextual chapters at the beginning and the conclusion with the eponymous title 'The Serious Game' - a formulation expressing Törnqvist's interpretation of Bergman's theatre as such metaphorically.

Törnqvist was one of the leading scholars in the field of Scandinavian studies and a significant part of his work aimed at international, mainly English-speaking audiences, so it is not surprising that his last book is carefully conceptualized to fit in. In the preface, Törnqvist comments on the previous publications of Bergman and his theatre work. The English reader can already use many books providing the general overview, such as Ingmar Bergman:
A Life in Theatre co-authored by Lise-Lone and Frederick J. Marker's (1992) or more than 300-page survey 'Ingmar Bergman in the Theatre' in Ingmar Bergman: A Reference Guide by Birgitta Steene (2015). Following these essential contributions, Törnqvist intends to introduce only chosen productions, paying attention to details, subtle dramaturgical changes, significant moments of actor's performance, creating rather analytical, in-depth book complementing these previous extensive publications.

The structure of the book corresponds with this choice: after a short preface, there is only one chapter entitled ' $\mathrm{B}$ \& Co.' giving very brief but condensed contextualization of Bergman's work in theatre, followed by fourteen chapters, each dedicated to one production, and then short conclusion. These analytical chapters on productions are quite independent, but Törnqvist is very methodical (and instructive) so that the chapters have almost identical structure. He introduces the play, its key dramaturgical issues and shortly touches upon the production's context, then he goes into detail. He describes general features of the stage design, the main dramaturgical perspective, and then demonstrates it on particular scenes. This is the strongest aspect of the book - Törnqvist's ability of vivid description and thoughtful choice of evocative details of the production (he 
intently choose only productions he witnessed himself or these which are videodocumented, which allows him to provide, when necessary, detailed transcripts of stage action).

The analytical chapters serve very well as particular arguments supporting the general characterization of Bergman's view on theatre as shown in the preface. Törnqvist describes him as a director heavily bearing on actors and acting, respecting their creativity but at the same time being very authoritative. Bergman's dramaturgy almost totally ignored the contemporary drama (from the theatre of absurd onwards) and relied mainly on 'classical' text in its wide sense; Bergman himself often expressed appreciation for these texts, their universality, and transcendent potential. Even though Törnqvist very often quotes Bergman's statements and often speaks from his perspective, at this point he immediately states, that these declarations do not contradict the simple and evident fact that Bergman sometimes did quite essential cuts and changes in his scripts. The characterization of this dramaturgical approach and its seemingly paradoxical nature is one of the leitmotifs of the book. It is not surprising that among the analysed productions, there are works based on Shakespeare, Ibsen, and Strindberg, joined by Moliere, O’Neill, Schiller, and Euripides, with Yukio Mishima's Madame de Sade being the only 'contemporary', or to be more accurate, post-war drama.

There are many inspiring samples of Bergman's directing choices and solutions described. His version of King Lear, interpreted almost like a morality play, working with the symbolic colours of costumes of both competing sides, foregrounding the topic of power and manipulation through the use of extras (representing figures of servants) as living props. The final moment is of particular importance (and is probably connected to Kott's readings of Shakespeare), as the only two surviving allies, Edgar and Albany, cross their swords and this image disappears in darkness with the sound of thunder - so the wheel of power struggle starts again. In Hamlet, Bergman searched for and highlighted motives of sacrifice and passion in its very Christian sense - for example the mad Ophelia handed Gertrude and others rusted nails instead of the 'traditional' flowers.

The respect for the author and the urge to interpret the plays in the actual social and emotional context might often lead to (very thoughtful and concise) adaptation which goes against the author's assumed intention. For example in Ibsen's Nora, there is only one child in the Helmer's family, a girl, who witnesses the crisis of her parent's relationship. This trauma will probably influence the girl in future as Nora herself is also a traumatized child. Such interpretation is possible partly through tracing the changes of the text and is partly demonstrated in the added pantomime scenes which reshape a story of the play into a new one. Subtle discussions of these changes and their dramaturgical implications constitute the core of the book.

In the case of Miss Julie, Törnqvist provides the reader with detailed discussion of different motivations for Julie's suicide, demonstrating Strindberg's intentions, historical background as well as Bergman's strategy of reinterpretation of these motivations so that it would be credible for his actual audience. Bergman eventually created complicated interplay between the stage and the costumes referring to the his- 
torical context (especially the stage design setting the whole production to the period of the play's origin) and searched for the actual significance of the production. For Törnqvist, (theatre-) directing is evidently the tool for controlling meaning and organizing spectator's focus; in the description of the final scene in Miss Julie, he says: 'She held her lifted arms so her position expressed both desperation and protection from the mortal blow; in addition the spectator's gaze was directed to her neck which was soon to be cut by her suicidal razor' (49). This concept would be suitable for many directors of Bergman's 'generation' or period, an approach which might be called late modernist directing. No matter how significant the alternations of the pretext are, Bergman still eventually creates his new coherent vision. (He, for instance, went so far, that he would insert small, obviously autobiographical, details into Ibsen's Ghosts so that the production would in times resemble a very personal confession.)

The overall idea of Bergman as the late modernist director emerges in all chapters. The issues Bergman is dealing with, the choices he is making and even the way he presents himself, remind methods and rhetoric of directors like Giorgio Stehler, Jean Villar or Otomar Krejča, to mention at least one widely known Czech based artist. Many issues discussed by the critics in Bergman's case, might be heard and read across the European theatre in the $1960 \mathrm{~s}$ and the $1970 \mathrm{~s}$, and are of great significance to the late development of modern directing (before the post-modern turn): director declaring truthfulness and respect to the dramatic text, but changing the text and its meaning fundamentally, certain tension between strong, almost omnipotent director and his complex vision, contrasting with the director's dependence on and respect and love for actors, the issues of modernization and actualization (especially in terms of visuality) but still attempting to preserve the original historical qualities of the drama. In stage design, there are also attempts to create a kind of community connection between the actors and the audience, yet still preserving the artificial nature of theatre art. All these features are not just about Bergman's theatre; they are much more general. They are the founding elements of the modern theatre as such but they perfectly fit the Bergmanesque context (and could be derived from Törnqvist detailed analyses and dramaturgical discussions in the book).

The only limitation of the book is that Törnqvist focuses only at Bergman and his theatre, despite doing his best to provide the reader with the period background. In the publication's conclusion, he sums up all the features of Bergman's approach without any further contextualisation and theoretical conceptualisation. This omission poses a challenge for the forthcoming generation of scholars, as there was quite a lot of work done in providing descriptions, overview and particular analysis, to bring Bergman's work from the closet of national genius, so he could be - together with his theatre productions - interpreted and evaluated in the European context. In the preface, Törnqvist states: 'Film is an international medium, theatre is a national one' (9). He uses this argument to explain why Bergman's theatre work, even though it twice outnumbers his movies, is rarely known outside Sweden. However, from his descriptions and analysis, one can at least hypothesise that certain 
features of directing approaches are re- of the modern European theatre as such. appearing in the modern theatre directing Already from reading Törnqvist's book, it around the whole of Europe. The com- is more than clear that such an adventure parison of different national theatre cul- would be worth trying and it would bring tures and theorising about these patterns more differentiated understanding to the might help conceptualise the development work and figure of Ingmar Bergman. 